UDC 332; DOI 10.18551/rjoas.2022-01.17

\title{
FORECASTING PRODUCTION AND CONSUMPTION OF RICE AND INFLUENCE OF DETERMINANTS TO INCREASE FOOD SECURITY IN THE SOUTH SUMATRA REGION, INDONESIA
}

\author{
Januarti Indri, Junaidi Yulian, Purbiyanti Erni \\ University of Sriwijaya, Indonesia \\ *E-mail: in drykrenz@yahoo.co.id
}

\begin{abstract}
The objectives of this study are (1) to analyze the rate of development of rice production and consumption in South Sumatra, (2) to analyze the factors that affect rice production and consumption in South Sumatra, including seeing the impact of a government policy or program ("Upsus" and Price Highest Retailing/ HET Rice) and climate change, and (3) analyzing forecasts of the amount of rice production and consumption in the next ten years and what the implications are for sustainable food security at the regional level in South Sumatra. The research method used is historical empirical research method. The data used are time series data for 33 years from 1987 to 2019. Analysis of the data used for the first purpose, namely analyzing the development of rice production and consumption in South Sumatra, is a descriptive analysis method with tabulation. Meanwhile, the second objective, namely regarding the factors affecting rice production and consumption in South Sumatra, was analyzed using multiple linear regression. Furthermore, to answer the third objective, which is to project rice production and consumption in South Sumatra in the next ten years, Holt's multiple exponential smoothing method is used. The result of this research shows that the development of rice production in South Sumatra Province in 1987-2019 tends to increase, with an average increase of 3.26 percent per year. Meanwhile, the development of rice consumption in South Sumatra Province from 1987-2019 also tended to increase, with an average increase of 0.54 percent. The determinants or factors that have a significant positive effect on rice production in South Sumatra Province are the harvested area, the price of unhulled rice and the policy dummy for the Special Efforts for SelfSufficiency Program for rice. The determinant or factor that has a significant positive effect on rice consumption in South Sumatra Province is the population. Meanwhile, the determinants or factors that have a significant negative effect are the price of rice and the dummy of the highest retail price ("Harga Eceran Tertinggi", HET) policy of rice. Based on the forecast results, during the next ten years, rice production and consumption in South Sumatra Province tends to increase but with different average growth. The average growth of rice production in South Sumatra Province is 1.67 percent per year, while the average rice consumption in South Sumatra Province is 0.88 percent. This condition will increase the production surplus for the next ten years, which means that South Sumatra Province can continue to improve regional food security and increase its contribution to national food availability. The average growth of rice production in South Sumatra Province is 1.67 percent per year, while the average rice consumption in South Sumatra Province is 0.88 percent. This condition will increase the production surplus for the next ten years, which means that South Sumatra Province can continue to improve regional food security and increase its contribution to national food availability. The average growth of rice production in South Sumatra Province is 1.67 percent per year, while the average rice consumption in South Sumatra Province is 0.88 percent. This condition will increase the production surplus for the next ten years, which means that South Sumatra Province can continue to improve regional food security and increase its contribution to national food availability.
\end{abstract}

\section{KEY WORDS}

Forecasting, production, consumption, food security, exponential smoothing. 
Food has an important meaning for a nation because it is a basic need and one of the human rights. If the demand for food is greater than the supply of food, it will cause economic instability, social and political turmoil, and in the end it will also disrupt national stability (Bulog, 2006). For this reason, food security has always been a concern for the Government of Indonesia, especially for the rice commodity as the staple food of most of the population.

According to the Republic of Indonesia Law Number 18 of 2012, food security can be defined as a condition of the availability of sufficient food in quantity and quality from the individual to the state level, safe, diverse, nutritious, equitable and affordable and does not conflict with religion, belief and culture, so that can live healthy, active and productive in a sustainable manner (Bulog, 2014). This definition is in line with the definition of food security according to FAO (2002), which states that food security is a condition in which every individual has physical and economic access to sufficient, safe and nutritious food to meet daily nutritional needs according to preferences and is guaranteed continuity. From this definition, it can be seen that food security includes several aspects, including availability.

Food availability is related to food supply, especially those from domestic production. Various attempts have been made by the government to increase domestic production. The increase in production is expected to increase food security and achieve sustainable selfsufficiency. To make it happen, the government's attention is focused more on regions or areas that have the potential to become national food barns. Moreover, according to the Ministry of Agriculture (2018), the Indonesian Government aspires to make Indonesia the world's food barn by 2045. For this reason, the Ministry of Agriculture must create and prepare policies or programs to improvefood security and make Indonesia as a world food barn carefully planning.

Food production is strongly influenced by climate. If food production that is vulnerable to climate change is not equipped with a strong food policy, it will be very detrimental to both producers and consumers, especially small-scale producers and low-income consumers and will disrupt the level of food availability. In addition, other obstacles such as the characteristics of agricultural commodities that are easily damaged, narrow land, inadequate facilities, and lack of harvest and post-harvest handling have made the Government to intervene in realizing food security.

Another problem that arises is in distribution. Most of the food stocks available in production areas must be distributed between regions or between islands. However, it is not uncommon for distribution facilities and infrastructure to be limited and sometimes more expensive than distribution from abroad. In terms of trading systems, the length of the supply chain has resulted in quite large differences in producer and consumer prices with control of the food trade in certain groups (Bulog, 2014). Meanwhile, from the consumption side, food is the biggest expenditure for households, over $50 \%$ of total expenditure (Bulog, 2014).

By considering the previous description, the national food policy must be able to accommodate and balance the aspects of domestic supply / production and demand for consumption. The management of these two aspects must be able to create a national food security that is resilient to all turmoil and must be done optimally. Hierarchically, food security can occur at the global, national, local or regional, household and individual levels. Therefore, to achieve national food security, first it is necessary to achieve regional or provincial food security.

One of the programs that have just been launched by the Government of Indonesia in 2019 is the Serasi Program (Save Rawa Welfare Farmers). This program is primarily aimed at mengoptimize the use of swampswhich is quite extensive in Indonesia and is expected to improve the lives of farmers. In addition, the program is a solution to the food problem. Increasing food production, especially rice, is focused on swamps, both low and low, one of which is due to the increasing conversion of agricultural land functions. South Sumatra is one of the provinces that has a large area of swamps, which have the potential to become agricultural land. The large potential of swamps in the area is used to increase rice production in South Sumatra Province.

From the previous description, it is only natural that the Minister of Agriculture Andi Amran Sulaiman (2019) targets the Province of South Sumatra (Sumsel), to increase its 
position as first place national food storagein Indonesia. Before supplying to the national level or higher, it must first achieve food security in the South Sumatra region itself. Talking about food security, it cannot be separated from the aspects of production and consumption as well as projections or forecasts in the future. For this reason, in this study, we will look at how the development of production over the last 30 years and projections or forecasts for the next 10 years can answer the question "Is it possible that the rice surplus in South Sumatra will increase and be sustainable?" so that it can support the achievement of food security at a higher level, both nationally and globally or in the world. In addition, factors that influence production and consumption will also be analyzed so that appropriate policies can be formulated.

\section{LITERATURE REVIEW}

Production is the process of coordinating various factors of production or resources to transform materials into products (goods) or services to meet consumer needs. Products (goods) are the results of the production process using various resources to create additional benefits, both form benefits, time benefits, space benefits and ownership benefits (Manullang, 2013).

The production function is generally written in a mathematical model in the form of:

$$
Y=f(X 1, X 2, \ldots, X n)
$$

Where: $Y=$ Production or variables influenced by factors of production; $X, X 1, ., X n=$ Factors of production or variables that affect $Y$.

The production function in agriculture according to Soekartawi (1990), Y can be agricultural production and $X$ is a production factor such as production inputs, namely agricultural land, labor, capital, and management, but in this case the production factor has not been able to explain $\mathrm{Y}$, so it is necessary understanding of the production process.

According to Daniel (2002) production factors, for example for one hectare of rice plants, so that maximum production can be achieved through given inputs (capital) such as the number of seeds, fertilizers, and medicines must be in accordance with what rice plants need. The method of administration, the time of administration, and the dose or dose of each application must also be appropriate, coupled with the selection of seeds, seeding, soil cultivation, weeding, fertilization, and others which are more commonly referred to as technology. Technology plays a role in determining the interrelationship between production factors such as the land area used for one hectare, so how much capital and labor is needed can be determined by determining the technology applied. Likewise, the available capital is limited or determined; the area of the farm must also follow.

According to Soekartawati (2002) in Hessie (2009), several known production function models include the linear, Cobb-Douglas, and transcendental models. The multiple linear model and the Cobb-Douglas model are the simplest and easiest models to analyze.

Consumption is an activity that aims to reduce or consume the usability of an object, both in the form of goods and services to meet needs and satisfaction directly (Nicholson, 1995). Consumption is a number of goods that are used directly by the community to meet their needs. Current consumption is almost perfectly predictable from consumption in the previous period plus a slight growth. Keynes stated that consumption was very dependent on current income. Therefore, economics states that consumers understand that they are faced with decisions over time. Consumers look at their future resources and needs, which are expressed in terms of a more complex consumption function than Keynes' consumption function. Keynes stated the form of the consumption function:

$$
\text { Consumption }=f(\text { current income })
$$

Whereas a recent study states: Consumption $=f$ (current income, wealth, expected future income, interest rate, and price of goods). 
In other words, current income is only one determinant of aggregate consumption (Mankiw, 2007).

Apart from income, consumption expenditure is also influenced by other consumption factors, namely: (1) Economic factors such as; (a) Household income because the higher the household income, the higher the level of consumption; (b) Household assets are real assets (including house, land, capital) and financial (shares, securities, time deposits). This wealth can increase consumption because it increases disposable income. For example, the interest on deposits received every month and dividends received each year increase household income; (c) The quantity of durable goods in society that has an influence on the level of consumption can be positive (increase) and negative (reduce). Durable goods are usually expensive and take a long time to save money to acquire; (d) The interest rate can affect consumption, from the perspective of the family that has both excess and lack of money; (2) Demographic factors such as; (a) A large population will increase consumption expenditure; (b) The composition of the population of a country can be seen from several classifications including age (productive and unproductive), education (low, middle, high), and region; (3) Non-economic factors, namely the socio-cultural factors of the community, for example changing or changing eating habits, ethical habits, and values because they want to follow or imitate other groups of people. (b) The composition of the population of a country can be seen from several classifications including age (productive and unproductive), education (low, middle, high), and region; (3) Non-economic factors, namely the socio-cultural factors of the community, for example changing or changing eating habits, ethical habits, and values because they want to follow or imitate other groups of people. (b) The composition of the population of a country can be seen from several classifications including age (productive and unproductive), education (low, middle, high), and region; (3) Non-economic factors, namely the socio-cultural factors of the community, for example changing or changing eating habits, ethical habits, and values because they want to follow or imitate other groups of people.

The consumption function is derived from demand theory. According to Wardojo in Rahayu (2016), to project rice consumption, several things are needed, namely: (1) Information regarding the elasticity of income for rice consumption; (2) Self-price elasticity; (3) Basic year population and population growth rate; (4) Estimated growth in per capita income of the community; and (5) Estimated price changes in the coming year. There are two approaches to projecting per capita rice consumption. First, considering that the level of rice consumption in 1999 was seen as not reflecting normal conditions, in projecting future consumption (2002-2004) the 1996 consumption level was used as the base year for 1999 . The second alternative is to keep using the 1999 per capita consumption level, as base year, but using the assumption of a higher increase in income and a lower increase in rice prices. This assumption is in line with the government's determination to control rice prices so that they can be affordable for poor households, for example by imposing restrictions on rice imports.

The demand and supply of agricultural goods or commodities is closely related to price developments, when prices rise, demand will fall and if prices fall, demand will rise. Conversely, if the supply rises, the price will fall and if the supply falls, the price will increase. This situation will always rotate in such a way as to create a mechanism known as the market mechanism. Prices will be regulated by the availability of goods, but this law may not apply when a price fixing policy occurs for a commodity related to the commodity being traded (Daniel, 2002).

Supply in the agricultural sector is the number of agricultural commodities produced or offered by farmers or producers. In the law of supply, it is stated that the higher the price of an item, the more the quantity of the good is offered by the producer, because the economic stimulus is high. Conversely, the lower the price, the less the quantity offered on the condition that other factors that also affect the supply, such as land area, weather, etc. do not change (cateris paribus) (Tambunan, 2003). The factors that influence supply are: (1) Production technology; (2) The price of the input used in the production process; (3) Prices of 
substituted goods; (4) Expected price; (5) The number of sellers in the market; (6) Taxes and subsidies associated with the amount of production.

Demand is defined as a schedule that shows the various quantities of products to be purchased at various levels in certain conditions and time periods. Demand for an agricultural commodity is the number of agricultural commodities that consumers need and buy (Soekartawati, 2002). Conceptually, demand is a function that is influenced by many variables (multivariate), the most important factors affecting demand are the price of the goods concerned, prices of other goods, income and tastes. According to Halcrow (1992) non-price factors that influence demand can be: (1) Consumer tastes and preferences; (2) The number of consumers in the market; (3) Consumer income or welfare; (4) Prices of other goods; (5) Consumers' expectations of prices and income in the future.

One of the most important economic symptoms related to people's behavior as both producers and consumers is price. Price is the most important thing in business activities, because an item that is sold must be priced in advance so that all parties can make a profit and get satisfactory results with the agreed price fixing. Price is a value of goods or services in the form of a sum of money for a good or service that must be paid by consumers to obtain or own a good or service.

According to Soemarsono in Wulandari (2003), there are three forms of determining the selling price, namely:

- The selling price is determined by the market, where the price is determined by the supply and demand mechanism;

- The government determines the selling price, the prices of goods and services, especially those related to the public interest, set by the government;

- The selling price which can be controlled by the company, the price is set by the seller by still paying attention to the government and bidding mechanism as well as government regulations.

According to Soekartawi (2006), all price policies are determined on the balance of input and output. Price policy is needed for various purposes, for example to protect producers so that they can still make a profit and to protect consumers so that consumers are not harmed. In the case of agricultural commodities, especially agricultural commodities which concern the interests of many people, the price policy is often regulated by the government. But for other commodities that are not regulated by the government, so the price of the goods is left to the market. The price policy regulated by the government is determined through two types of prices, namely the floor price and the ceiling price. If the market price is different between the two types, it means that the private sector can manipulate the selling price between the base price and the fixed price.

The Cobb Douglas production function was introduced by Cobb, CW and Douglas in 1928 through an article entitled A Theory of Production. The Cobb-Douglas production function, which is a function or equation that involves two or more variables, a variable called the independent variable $(L$ and $K$ ) and the other called the dependent variable $(\mathrm{Q})$. The Cobb-Douglas production function is a functional form of the production function widely used to represent the relationship of output to input. The Cobb-Douglas production function is generally concave normal or normal convex. The Cobb-Douglas production function is the function most often used in empirical research. The Cobb-Douglas production function is expressed by the following equation:

$$
Q=A L^{\alpha} K^{\beta}
$$

Where: $\mathrm{Q}=$ Total Production; $\mathrm{L}$ and $\mathrm{K}=$ Variable; $\alpha, \boldsymbol{\beta}=$ Output elasticity of each input.

This equation can be transformed into a linear logarithmic form as follows:

$$
\operatorname{Ln} Q=\ln A_{0}+b_{1} \ln K+b_{2} \ln L+u
$$

To solve the Cobb-Douglas function, which becomes a logarithmic form and is transformed into a linear function, several conditions are required. The requirements that 
must be met in the use of the Cobb-Douglas production function include (Soekartawatiin Tentoea, 2013):

- There is no observation of the explanatory variable which is equal to 0 because the logarithm of zero is a number whose value cannot be determined (infinite);

- In the production function it is assumed that there is no technological difference in each observation (non neutral difference in the respective technologies). In the sense that if the Cobb-Douglas production function is used as a model in an observation and if an analysis is needed that requires more than 1 model, the difference in the model lies in the intercept and not the slope of the model;

- Each independent variable is perfect competition;

- There is only one variable described or the dependent variable, namely (Q).

According to Makridakis et al (1991), commitment to forecasting growth is due to several factors. The first factor is the increasing complexity of the organization and its environment. Second, as the size of the organization increases, the weight and importance of decisions has also increased. Third, the environment of most organizations has changed rapidly. Fourth, decision-making has become increasingly systematic which includes explicit justification of individual actions. Fifth, that the development of forecasting methods and knowledge regarding their application has made it more possible to have direct application by practitioners than only by expert technicians. Quantitative forecasting can be applied when information is available about the past. follows:

There are two main types of forecasting models (Makridakis et al, 1991), which are as

1. Time series model, predicting the future is based on the past value of variable and / or past errors. The aim is to find patterns in historical data series extrapolating these patterns to the future;

2. The causal model (regression), the predicted factors show a causal relationship with one or more independent variables. The aim is to find the shape of the relationship and use it to predict the future value of the dependent variable.

Food security is a situation where all households have both physical and economic access to food for all family members, where households are not at risk of losing both accesses. Meanwhile, the definition of food security according to the Republic of Indonesia Law Number 7 of 1996 is a condition for the fulfillment of food for households which is reflected in the availability of sufficient food, both quantity and quality, safe, equitable and affordable.

The Food Security Council uses a food security system approach as an indicator in realizing food security, namely (1) availability of food in sufficient quantities and types for the entire population, (2) smooth and even distribution of food, (3) food consumption of each individual that meets adequacy of balanced nutrition, which has an impact on (4) the nutritional status of the community. Food availability, access and consumption are the main sub-systems, while nutritional status isoutcame of food security.

\section{METHODS OF RESEARCH}

This research method is an empirical historical research method, which aims to reconstruct past data systematically and objectively through collecting, assessing, verifying, and synthesizing evidence to establish facts and reach defensible conclusions. The data used is time series data from 1990 to 2019.

The research was conducted in South Sumatra Province. The location selection was done purposively (purposive) with the consideration that South Sumatra is one of the largest rice production provinces in Indonesia after Java and is the third contributor to the national food barn. Also, the government hopes that the region will become the largest rice contributor to the national food barn. The data collected is secondary data in annual form.

Data processing for the first purpose of this study used descriptive analysis method with tabulation, namely by analyzing the development of rice production and consumption in South Sumatra using a computer program, namely Microsoft Office Excel. Descriptive 
analysis in this paper is used to provide an explanation and interpretation of information and research data. The rate values used in analyzing rice production and consumption data in South Sumatra used in this study are:

$$
\text { The rate of production or consumption }=\frac{\text { the margin value of } \mathrm{P} \text { or } \mathrm{K}}{\text { the lag value of } \mathrm{P} \text { or } \mathrm{K}} \times 100 \%
$$

Where: Production or consumption rate $=$ Percent $(\%)$; the value of the difference in production or consumption $=\left(P_{t}-P_{t-1}\right)$ or $\left(K_{t}-K_{t-1}\right)$; the lag value of production or consumption $=\left(P_{t-1}\right)$ or $\left(K_{t-1}\right) ; \mathrm{P}$ and $\mathrm{K}=$ Production and Consumption; $\mathrm{t}=$ Production or consumption in year $\mathrm{t} ; \mathrm{t}-1=\mathrm{Lag}$ (Production or consumption in the previous year).

Data processing to analyze the determinants or factors that affect rice production and consumption in South Sumatra were analyzed using multiple linear regression with the Cobbdouglass type assisted by the Eviews computerized technique. This function is a function or equation that involves two or more variables. The equation formulated in this study is formulated from several previous studies contained in the theoretical framework, the assumed equations are: (1) domestic rice production, and (2) domestic rice consumption. The process of analyzing an econometric model consists of:

Rice production in South Sumatra is thought to be influenced by the area of rice harvested, grain prices, urea fertilizer prices, labor wages, rainfall and policy dummy. The equation for rice production in Indonesia can be written as follows:

$$
\operatorname{Ln} Y_{t}=c_{0}+c_{1} \operatorname{Ln} L A P_{t}+c_{2} \operatorname{Ln} H G_{t}+c_{3} \operatorname{Ln} H P U_{t}+c_{54} L n C H_{t}+c_{6} \operatorname{Ln} D_{t}+\operatorname{Ln} \mu
$$

Where: $\mathrm{PPt}=$ Rice production in year $\mathrm{t}$ (Thousand Tons); LAPt $=$ The area of rice harvested in year $\mathrm{t}$ (Thousand $\mathrm{Ha})$; HGt $=$ Price of grain in year $\mathrm{t}(\mathrm{Rp} / \mathrm{Kg})$; HPUt = Price of urea fertilizer in year $\mathrm{t}(\mathrm{Kg} / \mathrm{Ha}) ; \mathrm{CH} t=$ Rainfall in year $\mathrm{t}(\mathrm{mm}) ; \mathrm{Dt}=$ Policy Dummy (Oopsus Program); $c_{0}=$ Intercept; $c_{i}=$ Estimated parameter $(\mathrm{i}=1,2,3,4,5,6) ; \mu=$ Term of Error (bully error).

It is assumed that individual rice consumption in South Sumatra can be influenced by the price of rice, the population of South Sumatra, the GRDP per capita of South Sumatra and the price of maize as a substitute for food to replace rice. The equation for rice consumption in Indonesia can be written as follows:

$$
L n C o_{t}=c_{0}+c_{1} \operatorname{LnJP} P_{t}+c_{2} \operatorname{Ln} P D R B_{t}+c_{3} \operatorname{Ln} H B_{t}+c_{4} \operatorname{Ln} H J_{t}+c_{5} \operatorname{Ln} D_{t}+\operatorname{Ln} \mu
$$

Where: $\mathrm{KBt}=$ Individual rice consumption in year $\mathrm{t}(\mathrm{Kg} /$ year $)$; POPt $=$ Total population in year $\mathrm{t}$ (people / year); PDRBt $=$ PDRB Per Capita South Sumatra year $\mathrm{t}$ (Rp / year); $\mathrm{HBt}=$ Price of rice in year $\mathrm{t}(\mathrm{Rp} / \mathrm{Kg})$; $\mathrm{HJt}=$ Price of maize in year $\mathrm{t}(\mathrm{Rp} / \mathrm{Kg}) ; \mathrm{D}=$ Highest Retail Price Policy Dummy; $c_{0}=$ Intercept; $c_{i}=$ Estimated parameter $(\mathrm{i}=1,2,3,4) ; \mu=$ Term of Error (bully error); other independent variables.

Furthermore, to project rice production and consumption in South Sumatra in the next ten years, Holt's multiple exponential smoothing method is used. Holt's multiple exponential smoothing method does not use the direct multiple smoothing formula. Instead, Holt smoothed trend values with different parameters from the parameters used in the original series (Makridakis et al, 1991). The forecast of Holt's multiple exponential smoothing is obtained using two smoothing constants (values between 0 and 1) and three equations:

$$
\begin{gathered}
\mathrm{St}=\alpha \mathrm{Xt}+(1-\alpha)(\mathrm{St}-1+\mathrm{bt}-1) \\
\mathrm{Bt}=\mathrm{V}(\mathrm{St}-\mathrm{St}-1)+(1-\mathrm{V}) \mathrm{bt}-1 \\
\mathrm{Ft}=\mathrm{St}+\mathrm{btm}
\end{gathered}
$$

Where: $\mathrm{Ft}=$ forecast of consumption or production for year $\mathrm{t}$; $\mathrm{St}=$ basic value of consumption or production of beef; bt $=$ trend value; $\mathrm{m}=$ number of future periods to be forecast; 
$\mathrm{Xt}=$ actual value of beef consumption or production; $\alpha=$ smoothing constant (with a value between 0 and 1 ) $; ~ y=$ smoothing constant (with a value between 0 and 1).

Equation (3.1) adjusts St directly for the trend of the previous period, namely bt-1, by adding the final smoothing value, which is St-1. This helps remove lags and puts St on the basis of the current data value estimate. Then equation (3.2) rejuvenates the trend, which is shown as the difference between the last two smoothing values. This is true because if there is a trend in the data, the new value will be higher or lower than the previous value. Since there may still be a bit of randomness, this is eliminated by smoothing out the $\mathrm{Y}$ (gamma) trend in the last period (St - St-1) and adding it to the estimated previous trend multiplied by $(1-\mathrm{y})$. Finally, equation (3.3) is used to predict the future.

This method is good for annual data that has trend data patterns. In addition, this method is used because it is simpler and easier to apply. Data processing in this analysis uses eviews software.

\section{RESULTS AND DISCUSSION}

The rice production referred to in this research is the entire total yield from the conversion of rice in tonnes per year. According to the Food Security Agency, the percentage of conversion from paddy to rice is 63.50 percent. The development of rice production in South Sumatra in 1987-2019 can be seen in Figure 1. During this period, rice production tended to increase, with an average increase of 3.26 percent per year. From 1987 to 1990, rice production in South Sumatra increased from $773,982.45$ tons to 906,86446 tons. The increase in rice production was partly influenced by the existence of the harvested area which tended to increase by 2.12 percent per year during the 1987-1990 period. However, there was a decrease in rice production in 1991 to $780,327.37$ tons or a decrease of around 13, 95 percent from the previous year. The decline in rice production in 1991 was caused by the long dry season.

A significant decrease in rice production also occurred in 1999, namely a decrease of 7.33 percent from 1998. This condition was caused by the El-Nino disaster in 1998 so that it affected the number of harvests the following year. The decline in production was also caused by a decrease in harvested area due to land conversion, use of less quality inputs, degradation of land quality, relatively low yield of rice and inappropriate post-harvest technology (Firdaus et al, 2008). After the conditions in 1999, the rice growth rate tended to increase by 5.71 percent per year during the 2000-2007 period. Increased production is driven by an increase in planted area and productivity (Firdaus et al, 2008). During that time period, a sizeable amount of production occurred in 2007, namely $1.748182,94$ tons or an increase of 12.08 percent from 2006. This was probably driven by the National Rice Production Increase (P2BN) policy in early 2007 (Firdaus, 2008). In addition, production growth was also triggered by the existence of price policies, both the Base Price and the Government Procurement Price, which aimed to reduce losses to rice producers due to falling prices at harvest (Firdaus, 2008).

The highest amount of production during the 1987-2019 period was achieved in 2016, namely $3,222,379,26$ tons. In 2016, the rice harvested area was also the highest during that time, namely $1,014,351.00 \mathrm{Ha}$. According to the Ministry of Agriculture of the Republic of Indonesia (2016), high rice production in 2016 was due to various government programs in 2015 , namely early anticipation and handling of massive drought including distribution of pumps and other agricultural machinery, rehabilitation of reservoirs, long-storage, rehabilitation of irrigation networks. , artificial rain and others as well as the Acceleration of Rice Planting Movement in November 2015. Furthermore, the 2016 program includes the provision of agricultural machinery and planting brigades, building reservoirs and longstorage, swamp irrigation, paddy fields expansion, dry land expansion, irrigation rehabilitation, land optimization, row cropping patterns. legowo, assistance with superior seeds with an allocation greater than 2015 as well as massive assistance to farmers by the hard work of extension workers, Babinsa, KTNA, Lecturers and Students are believed to also have an impact on high production in 2016 (Kementan RI, 2016). Then, in the last three 
years (2017-2019) production decreased from 2016, with production sizes of $3,219,359.83$ tons, 1,901,311.92 tons and 1,653,156.46 tons, respectively (BPS, 2018-2020). The decline in rice production is partly due to a decrease in the harvested area for this commodity. in the last three years (2017-2019) production decreased from 2016, with production sizes of $3,219,359.83$ tons, $1,901,311.92$ tons and 1,653,156.46 tons, respectively (BPS, 2018-2020). The decline in rice production is partly due to a decrease in the harvested area for this commodity. in the last three years (2017-2019) production decreased from 2016, with production sizes of $3,219,359.83$ tons, $1,901,311.92$ tons and $1,653,156.46$ tons, respectively (BPS, 2018-2020). The decline in rice production is partly due to a decrease in the harvested area for this commodity.

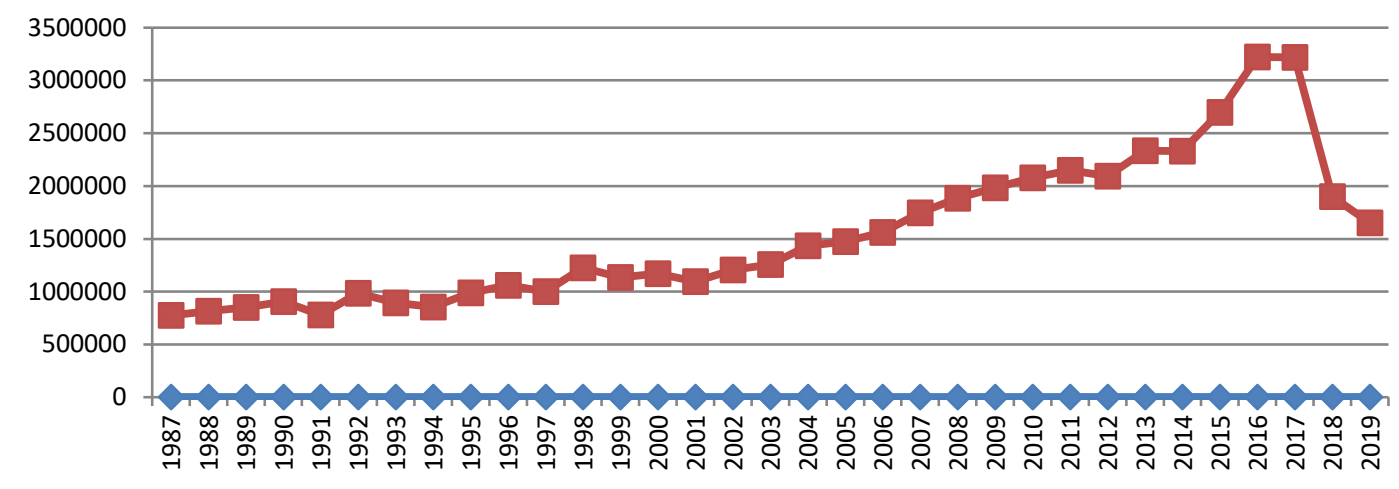

Figure 1 - Development of Rice Production in South Sumatra, 1987-2019 (Source: BPS, 1988-2020, processed)

The development of rice consumption in South Sumatra in 1987-2019 can be seen in Figure 2. During this period, rice consumption tends to increase, with an average increase of 0.54 percent. The rate of consumption growth was slower than the production growth rate (3.26 percent) during the period 1987-2019. This condition causes a surplus of rice production in South Sumatra Province, which can contribute to the national food supply. The highest rice consumption during the period 1987-2019 occurred in 2015, amounting to $789,529.49$ tons.

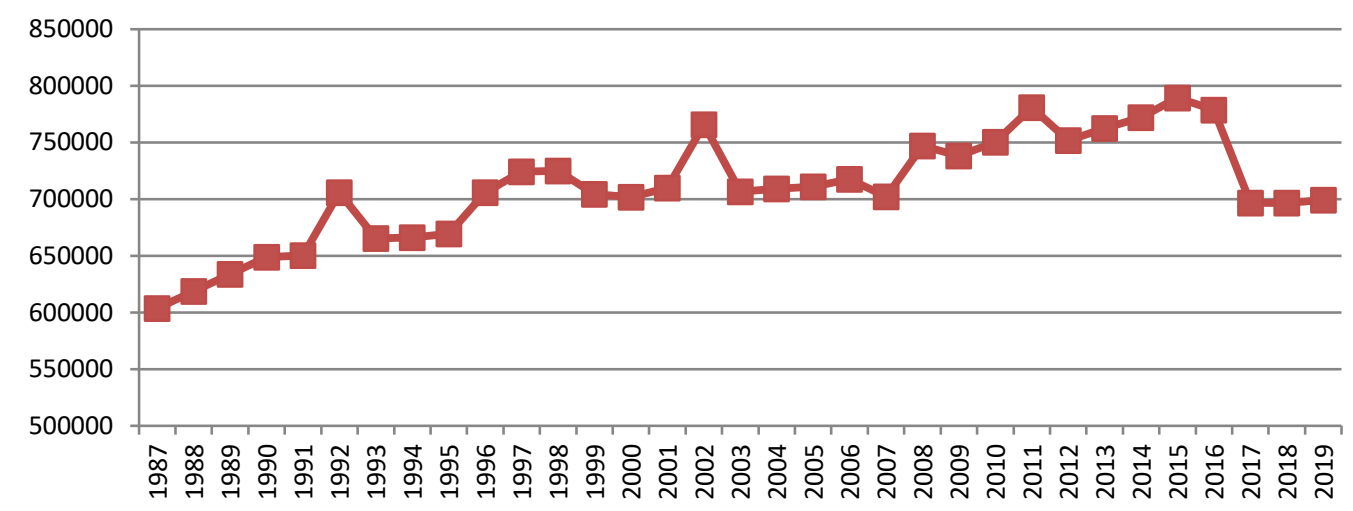

Figure 2 - Development of Rice Consumption in South Sumatra, 1987-2019 (Source: BPS, 1988-2020, processed)

The analysis used to determine the determinants or factors affecting rice production and consumption in South Sumatra Province uses a Cobb-Douglass type function. The computer program used is Eviews. In this study, the formation of a model of production factors that affect rice production in South Sumatra, namely harvested area, grain price, urea fertilizer price, labor wages, and rainfall. As for the consumption factors that affect rice consumption in South Sumatra, namely the population of South Sumatra, South Sumatra's GRDP, rice prices and maize prices. 
The rice production function is obtained by entering the independent variables that are estimated to affect domestic rice production in a multiple linear regression equation with the Cobb-Douglas function which is then transformed using the normal logarithm (Ln). From the results of data analysis, the $\mathrm{R} 2$ value of the rice production equation in South Sumatra Province is 0.9246 , which means that 92.46 percent of the rice production variable in South Sumatra Province can be explained by variations in the area of harvested, grain prices, urea fertilizer prices, bulk, rain and dummy upsus program. The results of the analysis of the estimated rice production function in South Sumatra Province are presented in Table 1.

Table 1 - Estimation Results of Rice Production Equation in South Sumatra Province

\begin{tabular}{lllll}
\hline Variable & Notation & Estimated Parameter Value & T-Statistics & Probability \\
\hline (Constant) & C & $-4,2695$ & $-1,8295$ & 0.0784 \\
Harvested Area & InLAP & 1,1742 & 7,3997 & $0.0000^{* * *}$ \\
Prices of Grain & InHG & 0.3481 & 4,1384 & $0.0003^{* * *}$ \\
Urea Fertilizer Prices & InHPU & -0.1316 & -1.3342 & 0.1933 \\
Rainfall & InCH & 0.1353 & 1.4866 & 0.1487 \\
Dummy ProgramUpsus & DUpsus & 0.1911 & 2,3709 & $0.0251^{* *}$ \\
\hline R-squared & 0.9246 & & & \\
R-squared (adj) & 0.9107 & & & \\
F statistic & 66,2588 & & & \\
Prob (F-stat) & 0.0000 & & & \\
\hline
\end{tabular}

Note: ${ }^{* *}=$ significant at $\alpha=0.01 ;{ }^{* *}=$ significant at $\alpha=0.05 ;{ }^{*}=$ significant at $\alpha=0.10$.

The results of the partial test analysis of the factors affecting rice production in South Sumatra Province are as follows:

1. Harvested area. Variable The harvested area has a significant effect on rice production in South Sumatra Province at 99 percent confidence interval. If the harvested area increases by 1 percent, the amount of rice production will also increase by 1.17 percent. This is consistent with the production theory that input affects output or the amount produced (Lipsey et al, 1995). The results of this analysis are also in line with the findings of Onibala et al (2017) and Ishaq (2016) that land area has a positive effect on rice production;

2. Prices of Grain. Variable The price of unhulled rice has a significant effect on rice production in South Sumatra Province at 99 percent confidence interval. If the price of unhulled rice increases by 1 percent, the amount of rice production will also increase by 0.35 percent;

3. Upsus program. The Upsus program, which began in 2014 , has a significant effect on rice production in South Sumatra Province at 95 percent confidence interval. If the upsus program is applied, the production will increase by 0.19 times compared to if there are no upsus.

Table 2 - Estimation Results of the Rice Consumption Equation in South Sumatra Province

\begin{tabular}{lllll}
\hline Variable & Notation & Estimated Parameter Value & T-Statistics & Probability \\
\hline (Constant) & C & 2,6758 & 2,1639 & 0.0395 \\
Price of Rice & LnHB & -0.0648 & $-1,6981$ & $0.1010^{*}$ \\
Total population & LnJP & 0.7241 & 8,0201 & $0.0000^{* * *}$ \\
South Sumatra's GRDP & InPDRB & -0.0148 & $-1,5293$ & 0.1378 \\
Prices of Corn & LnHJ & 0.0260 & 0.7855 & 0.4390 \\
HET Policy Dummy & Dhet & -0.1306 & $-9,0806$ & $0.0000^{* * *}$ \\
& & & & \\
\hline R-squared & 0.9381 & & & \\
R-squared (adj) & 0.9266 & & & \\
F statistic & 81.7937 & & & \\
Prob (F-stat) & 0.0000 & & & \\
\hline
\end{tabular}

Note: ${ }^{* *}=$ significant at $\alpha=0.01 ;{ }^{* *}=$ significant at $\alpha=0.05 ;{ }^{*}=$ significant at $\alpha=0.10$.

Consumption is the use of goods and services to meet human needs. From the results of data processing, the $\mathrm{R} 2$ value of the rice consumption equation is 0.9381 , meaning that 
93.81 percent of the rice consumption variable in South Sumatra Province can be explained by variations in rice prices, population, South Sumatra GRDP, corn prices and dummy retail price policies. highest (HET) while the remaining 6.19 percent is explained by other variables outside the model.

The results of the partial test analysis of the factors affecting rice consumption in South Sumatra Province are as follows:

1. Price of Rice. Variable The price of rice has a significant effect on rice consumption in South Sumatra Province at 90 percent confidence interval. If the price of rice increases by 1 percent, the total consumption of rice decreases by 0.06 percent. The percentage change in consumption is smaller than the percentage change in price or is inelastic because rice is the staple food;

2. Total Population. Variable Total population has a significant effect on rice consumption in South Sumatra Province at 99 percent confidence interval. If the population increases by 1 percent, the amount of rice consumption will also increase by 0.72 percent;

3.The Highest Retail Price (HET) Policy. The policy for the highest retail price (HET) for rice came into effect in 2017. The dummy variable for the HET policy has a significant effect on rice consumption in South Sumatra Province at 99 percent confidence interval. If the HET policy is implemented, consumption will decrease 0.13 times compared to if there was no policy. According to consumers, the price of rice has become slightly more expensive.

Result forecasting or projection with Holt's multiple exponential smoothing method is one of the time series forecasting methods, this method is only based on the past value of a variable and / or past errors. The purpose of the time series method is to find patterns in historical data series and extrapolate patterns in historical data series and extrapolate these patterns to the future (Makridakis, 1991). The advantage of this method can be used to easily predict but does not consider other factors besides the variable time. The analysis was carried out with Eviews software, the results can be seen in Table 2.

Table 2 - Forecasting Production and Consumption, 2020-2029

\begin{tabular}{llll}
\hline Year & $\begin{array}{l}\text { Forecasting } \\
\text { Production (ton) } \\
(1)\end{array}$ & $\begin{array}{l}\text { Forecasting } \\
\text { Consumption (ton) } \\
(2)\end{array}$ & $\begin{array}{l}\text { Difference } \\
(3)=(1)-(2)\end{array}$ \\
\hline 2020 & $1,683,258.44$ & $707,943.37$ & $975,315.07$ \\
2021 & $1,713,360.41$ & $714,375.31$ & $998,985.10$ \\
2022 & $1,743,462.39$ & $720,807.24$ & $1,022,655.15$ \\
2023 & $1,773,564.37$ & $727,239.18$ & $1,046,325.19$ \\
2024 & $1,803,666.34$ & $733,671.12$ & $1,069,995.22$ \\
2025 & $1,833,768.32$ & $740,103.05$ & $1,093,665.27$ \\
2026 & $1,863,870.30$ & $746,534.99$ & $1,117,335.31$ \\
2027 & $1,893,972.27$ & $752,966.93$ & $1,141,005.34$ \\
2028 & $1,924,074.25$ & $759,398.86$ & $1,164,675.39$ \\
2029 & $1,954,176.23$ & $765,830.80$ & $1,188,345.43$ \\
\hline Average & $1,818,717.33$ & $736,887.09$ & $1,081,830.25$ \\
\hline
\end{tabular}

It can be seen that over the next ten years, rice production and consumption in South Sumatra Province tends to increase but with different average growth. The average growth of rice production in South Sumatra Province is 1.67 percent per year, while the average rice consumption in South Sumatra Province is 0.88 percent. This condition causes the widening gap between rice production and consumption in South Sumatra Province over the next ten years.

From the results of the previous analysis, to increase production so that South Sumatra Province can improve regional food security that is sustainable and is able to make a greater contribution to national food availability, efforts are needed, including:

1. Increased Prices of Grain. In order to protect the interests of farmers, the government since 2005 has implemented the Government Purchase Price (HPP) policy. The price of rice or grain output encourages farmers to further increase their production, with the hope of increasing their income and welfare. Therefore, to increase production required an increase in grain prices; 
2. Self-sufficiency Special Effort Program (Upsus) and similar programs. The Upsus program, which was started in 2014, has had a significant effect on rice production in South Sumatra Province. From the results of this analysis, with the UPSus program, rice production can be increased. For that, it is necessary to have an upsus program or similar program that can increase production;

3. Review the Highest Retail Price (HET) Policy. The policy of the highest retail price (HET) for rice which was implemented in 2017 has a significant effect on rice consumption in South Sumatra Province. Policies designed to protect consumers have the opposite effect. With the HET policy, rice consumption fell 0.13 times compared to if there was no policy, because according to consumers, the price of rice was slightly more expensive. But on the other hand, this reduction in consumption is beneficial in increasing sustainable selfsufficiency. Therefore, it is better for the government to review the implementation of this HET policy, to compare the positive or negative benefits that are obtained.

\section{CONCLUSION}

Based on the results of this study, it can be concluded that:

1. The development of rice production in South Sumatra Province in 1987-2019 tended to increase, with an average increase of 3.26 percent per year. Meanwhile, the development of rice consumption in South Sumatra Province from 1987-2019 also tended to increase, with an average increase of 0.54 percent. The growth rate of consumption is slower than the growth rate of production during the period 1987-2019. This condition causes a surplus of rice production in South Sumatra Province which can increase regional food security and contribute to national food reserves;

2. From the results of the analysis, it can be seen that the determinants or factors that have a significant positive effect on rice production in South Sumatra Province are the harvested area, the price of grain and the policy dummy for the Special Efforts for SelfSufficiency Program;

3. From the analysis it can be seen that the determinant or factor that has a significant positive effect on rice consumption in South Sumatra Province is the population. Meanwhile, the determinants or factors that have a significant negative effect are the price of rice and the dummy of the highest retail price (HET) policy of rice;

4. Based on the forecast results, over the next ten years, rice production and consumption in South Sumatra Province tends to increase but with different average growth. The average growth of rice production in South Sumatra Province is 1.67 percent per year, while the average rice consumption in South Sumatra Province is 0.88 percent. This condition will increase the production surplus for the next ten years, which means that the Province of South Sumatra can continue to improve regional food security and increase its contribution to national food availability.

\section{ACKNOLEDGEMENTS}

Our great attitude is expressed to Sriwijaya University that provided the research funding assistance from DIPA Fund Unsrischeme Research Lecturer of Sateks Year 2020 as well as to various parties that provided their assistance in this research.

\section{REFERENCES}

1. Alihamsyah, T. 2002. Prospek pengembangan and pemanfaatan lahan pasang surut dalam perspektif eksplorasi sumber pertumbuhan pertanian masa depan. Monograf Balai Penelitian Pertanian Lahan Rawa. Banjarbaru.

2. Borjas, G., J. 2010. Labour Economics, 5th Ed. The Mc Graw-Hill Companies Inc, NY.

3. Bulog. 2014. Ketahanan Pangan. Bulog. Jakarta (www.bulog.go.id).

4. Dewan Ketahanan Pangan. 2006. Kebijakan Umum Ketahanan Pangan 2006-2009. Dewan Ketahanan Pangan. Jakarta. 
5. Dewi, Windu U.S. 2011. Analisis Ketahanan Pangan Tingkat Rumah Tangga Petani di Kabupaten Bantul. Tesis Ekonomi Pertanian, Universitas Gadjah Mada. Yogyakarta.

6. Effendi, S. and Masri Singarimbun. 1989. Metode Penelitian Survei. LP3ES. Jakarta.

7. Elam, Emmett w. and Shelby H. Holder. 2015. An Evaluation of the Rice Outlokk and Situation Price Forecasts. J. of Agricultural and Applied Economics: 17(20), 155-162.

8. FAO (Food and Agriculture Organization). 2002. Declaration of the World Food Summit: Five Years Later, International Alliance against Hunger. FAO. Rome.

9. Firdaus, M., Lukman M.B., and Purdiyanti P. 2008. Swasembada Beras dari Masa Ke Masa: Telaah Efektivitas Kebijakan and Perumusn Strategi Nasional. IP Press. Bogor

10. Irawan, B. 2005. Konversi Lahan Sawah: Potensi Dampak, Pola Pemanfaatannya, and Faktor Determinan. Forum Penelitian Agro Ekonomi. Badan Litbang Deptan. Jakarta.

11. Irawan, N.C. 2010. Ketahanan Pangan and Kesejahteraan Rumah Tangga Tani di Kabupaten Sleman, Bantul and Kulonprogo. Tesis Ekonomi Pertanian, Universitas Gadjah Mada. Yogyakarta.

12. Januarti, Indri. 2012. Dampak Kebijakan Raskin terhadap Ketahanan Pangan Rumahtangga Petani di Desa Tanjung Pering, Kecamatan Inderalaya Utara, Kabupaten Ogan Ilir. Laporan Penelitian Dosen Muda "Sateks" Unsri. Inderalaya.

13. Kementerian Pertanian RI. 2016. Produksi Padi Tahun 2016 Diprediksi Tertinggi. (www.pertanian.go.id/home/?show=news\&act=view\&id=1614)

14. Nasution, D.D. 2020. Data BPS: Produksi Beras 2019 Turun Akibat Cuaca Ekstrem. (https://republika.co.id/berita/)

15. Nazir, M. 2009. Metode Penelitian. Ghalia Indonesia. Jakarta.

16. Omotesho, O.A., Adewumi M.O., and Fadimula K.S. 2007. Food Security and Poverty of the Rural Household in Kwara State, Nigeria A.A.A.E. Conference Proceedings. Department of Agricultural Economics and Farm Management, Faculty Agriculture, University of Ilorin, Nigeria.

17. Pankomera, P., Houssou N., and Zeller M. 2009. Household Food Security in Malawi: Measurement, Determinant, and Policy Review. Conference on International Research on Food Security, Natural Resources Management and Rural Development.

18. Purwaningsih, Y. 2010. Analisis Permintaan and Ketahanan Pangan Tingkat Rumah Tangga di Provinsi Jawa Tengah. Disertasi Ilmu Pertanian Universitas Gadjah Mada.

19. Salim, Handewi P. and Ariningsih E. 2008. Perubahan Konsumsi and Pengeluaran Rumah Tangga di Pedesaan: Analisis Data Susenas 1999-2005 Analisis Sosial Ekonomi and Kebijakan Pertanian, Bogor. Makalah disampaikan pada Seminar Nasional Dinamika Pembangunan Pertanian and Pedesaan pada tanggal 19 November 2008.

20. Rochman, J., Soejitno, Soeprapto, M. and Suwalan. 1991. Pengendalian Hama Tanaman Pangan Dalam Sistem Usahatani Lahan Pasang Surut. Risalah Seminar Usahatani di Lahan Pasang Surut and Rawa. Bogor, 19 - 21 September 1989.

21. Suriadikarta, D. A. and Mas Teddy Sutriadi. 2007. Jenis-Jenis Lahan Berpotensi Untuk Pengembangan Pertanian Di Lahan Rawa. Jurnal Litbang Pertanian.

22. Suryana, dkk. 2009. Kedudukan Padi dalam Perekonomian Indonesia. Departemen Pertanian (http://www.litbang.deptan.go.id/special/padi/bbpadi_2009_itkp_02.pdf).

23. Suryaningrum, Dewi Padmisari. 2012. Dampak Human Capital terhadap Produksi and Pendapatan Usahatani Paprika hidroponik di Desa Pasirlangu Kecamatan Cisarua Kabupaten Bandung Barat. Tesis UGM. Yogyakarta.

24. Suwarno and T. Suhartini. 1993. Perbaikan Varietas Padi untuk Menunjang Usahatani di Lahan Pasang Surut and Lebak. Dalam Prosiding Simposium Penelitian Tanaman Pangan III. Jakarta/Bogor, 23 - 25 Agustus 1993.

25. Wahyuni, Iriana. 2012. Analisis Risiko Produksi and Perilaku Penawaran Cabai Merah di Desa Perbawati (www.repository.ipb.ac.id/browse?value= Wahyuningsih\%2C+Iriana).

26. Yurisinthae, Erlinda. 2012. Risiko Produksi Usahatani Padi Pada Lahan Pasang Surut di Kabupaten Kubu Raya. Jurnal Agri Peat, 12 (2). 